\title{
Characterizing the effects of different chemicals on stem bending of cut snapdragon flower
}

\author{
May Thu Soe ${ }^{1+}$, Aung Htay Naing ${ }^{1+}{ }^{+}$, Soo Rin $\mathrm{Kim}^{2}$ and Chang Kil Kim*
}

\begin{abstract}
Background: This study investigated the effects of ethylene release compounds (ethephon), ethylene-action inhibitors (silver thiosulfate: STS), and nitric oxide donor (sodium nitroprusside: SNP) on stem bending of snapdragon flowers. Moreover, the effects of plant growth supplements [6-benzyladenine (BA), gibberellic acid $3\left(\mathrm{GA}_{3}\right)$, and calcium chloride $\left.\left(\mathrm{CaCl}_{2}\right)\right]$ on the stem bending were also extensively investigated.

Results: Ethephon completely prevented stem bending until 9 days after treatment (9 DAT). STS exhibited the highest bending rate, while SNP did not significantly affect the bending compared to the controls. The bending results were associated with the results of stem curvature, relative shoot elongation, ethylene production, and lignin content, that are involved in the stem bending mechanism. This was proven by the expression analysis of genes involved in ethylene and lignin biosynthetic pathways. The addition of plant growth supplements slightly or significantly delayed stem bending in the treatments (control, SNP, and STS) and significantly reduced petal senescence in ethephon at 9 DAT.
\end{abstract}

Conclusion: These results show the preventive role of ethephon in the stem bending of cut snapdragon. Moreover, the combination of ethephon with supplements also provided information that could guide the development of strategies to delay stem bending in other cut flowers that undergo serious bending during a short vase life.

Keywords: Ethylene production, Gene expression, Growth supplements, Lignin content, Petal senescence

\section{Introduction}

Snapdragon (Antirrhinum majus L.) is widely used as a cut flower in the floricultural industry due to its diverse and attractive colors [1]. However, the occurrence of stem bending during a short vase life period is a major postharvest problem of cut snapdragon flowers, which threatens flower growers and users. Generally, stem bending of cut flowers is associated with a poor lignification mechanism during stem elongation [2-4]; the reduction of

\footnotetext{
*Correspondence: ckkim@knu.ac.kr

${ }^{\dagger}$ May Thu Soe and Aung Htay Naing equally contributed to this work

1 Department of Horticulture, Kyungpook National University, Daegu 41566, South Korea

Full list of author information is available at the end of the article
}

lignin content weakens the rigidity of the stem and the vascular tissue which supports the water and minerals in the xylem, thus reducing the mechanical resistance of the whole flowers as well as disrupting water and mineral transport to the flowers and leading to stem bending.

Efforts have been made to overcome poor lignification mechanisms and therefore improve stem bending using ethylene-action inhibitors, such as silver thiosulfate (STS) and 1-methylcyclopropene (1-MCP) [5-8]. Celikel et al. [5] and Woltering et al. [8] claimed that STS or 1-MCP did not significantly affect the stem bending of snapdragon, whereas Philosoph-Hadas et al. [6, 7] stated that STS can block the gravitropic response of flowers. Conversely, the ethylene-releasing compound 2-chloroethylphosphonic acid (Ethephon) has been shown to inhibit original author(s) and the source, provide a link to the Creative Commons licence, and indicate if changes were made. The images or other third party material in this article are included in the article's Creative Commons licence, unless indicated otherwise in a credit line to the material. If material is not included in the article's Creative Commons licence and your intended use is not permitted by statutory regulation or exceeds the permitted use, you will need to obtain permission directly from the copyright holder. To view a copy of this licence, visit http://creativecommons.org/licenses/by/4.0/. The Creative Commons Public Domain Dedication waiver (http://creativeco mmons.org/publicdomain/zero/1.0/) applies to the data made available in this article, unless otherwise stated in a credit line to the data. 
stem elongation, which accelerates the stem bending of cut flowers [2, 9-11], and its application in vase life solution delayed stem bending of cut tulip and snapdragon flowers $[2,11]$. Ethephon has been shown to have promoting effects on lignification [2, 12, 13]. Delaying of stem bending by sodium nitroprusside (SNP) has been reported in gerbera and Calendula officinalis L. [3, 14, 15], whereas SNP promoted lignification and delayed the stem bending in cut gerbera [3]. Although ethephon has a promoting effect on lignification and preventive effect on stem bending $[2,11-13]$, as described above, the ethylene inhibitors STS or 1-MCP blocked the gravitropic bending of snapdragon $[6,7]$. In addition, the effect of SNP on stem bendingylene-induced changes in lignificatio in snapdragon has not been investigated. Therefore, it is interesting to investigate how these chemicals (ethephon, STS, and SNP) affect the stem bending of the cut snapdragon.

van Doorn et al. [11] and Naing et al. [2] observed that ethephon rapidly enhanced petal senescence due to overproduction of ethylene. van Doorn et al. [11] revealed the negative effect of ethylene on petal senescence by adding the supplements gibberellic acid $\left(\mathrm{GA}_{3}\right)$, benzyl adenine (BA), and calcium chloride $\left(\mathrm{CaCl}_{2}\right)$ to the vase solution, however, Naing et al. [2] did not test the effects of the
Table 1 Effect of ethephon, STS, and SNP alone or in combination with supplements on stimulation of curvature degree of stems at 3, 6, and 9 days after treatment

\begin{tabular}{llrr}
\hline Treatment & \multicolumn{3}{l}{ Curvature (degree) } \\
\cline { 2 - 4 } & 3D & 6D & 9D \\
\hline Control & $33 \pm 7 \mathrm{a}$ & $48 \pm 4 \mathrm{c}$ & $49 \pm 4 \mathrm{c}$ \\
STS & $30 \pm 9 \mathrm{~b}$ & $72 \pm 4 \mathrm{a}$ & $148 \pm 6 \mathrm{a}$ \\
SNP & $26.5 \pm 4 \mathrm{c}$ & $35 \pm 4 \mathrm{~d}$ & $46 \pm 4 \mathrm{c}$ \\
Ethephon & $20 \pm 2 \mathrm{~d}$ & $22 \pm 4 \mathrm{e}$ & $22 \pm 4 \mathrm{e}$ \\
Control $+\left(\mathrm{BA}_{1} \mathrm{GA}_{3}, \mathrm{CaCl}_{2}\right)$ & $20 \pm 2 \mathrm{~d}$ & $23 \pm 4 \mathrm{e}$ & $27 \pm 4 \mathrm{~d}$ \\
STS + $\left(\mathrm{BA}, \mathrm{GA}_{3}, \mathrm{CaCl}_{2}\right)$ & $28.3 \pm 3 \mathrm{c}$ & $58 \pm 4 \mathrm{~b}$ & $101 \pm 5 \mathrm{~b}$ \\
SNP + $\left(\mathrm{BA}, \mathrm{GA}_{3}, \mathrm{CaCl}_{2}\right)$ & $15 \pm 4 \mathrm{e}$ & $22 \pm 3 \mathrm{e}$ & $23 \pm 5 \mathrm{e}$ \\
Ethephon $+\left(\mathrm{BA}_{1} \mathrm{GA}_{3}, \mathrm{CaCl}_{2}\right)$ & $22 \pm 3 \mathrm{~d}$ & $23 \pm 2 \mathrm{e}$ & $23 \pm 2 \mathrm{e}$ \\
\hline
\end{tabular}

Data represent the mean of three replicates, and error bars indicate the standard error. Means with the same letters are not significantly different according to the least significant difference test $($ LSDT, $\mathrm{p}<0.05)$

supplement on the reduction of petal senescence in cut snapdragon. Therefore, the combined effects of the treatments (ethephon, STS, and SNP) with supplements on stem bending and petal senescence of snapdragon should be investigated.

In this study, we treated snapdragon cut flowers with ethephon, STS, and SNP and investigated their roles in
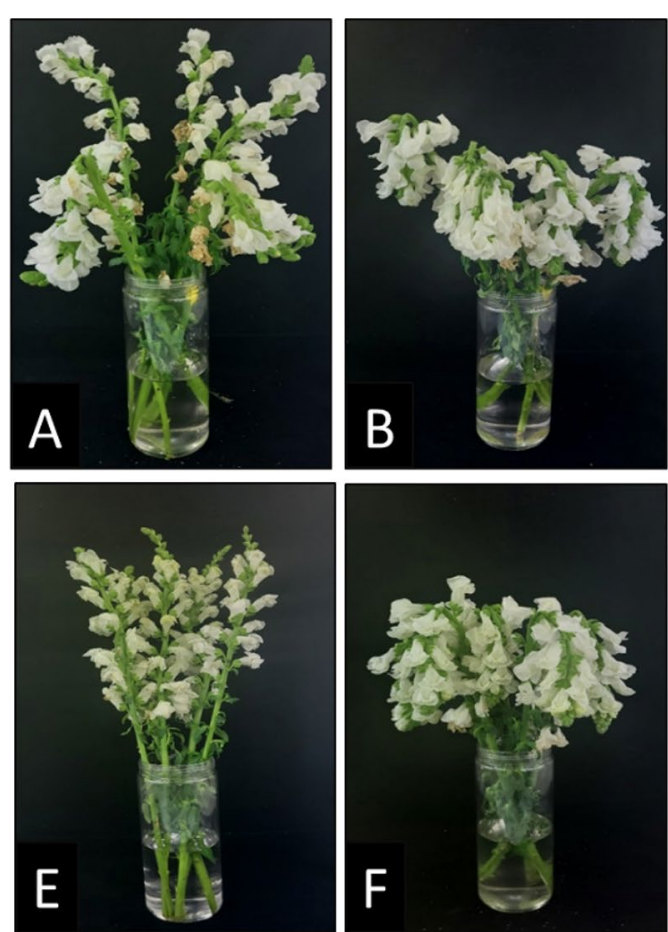
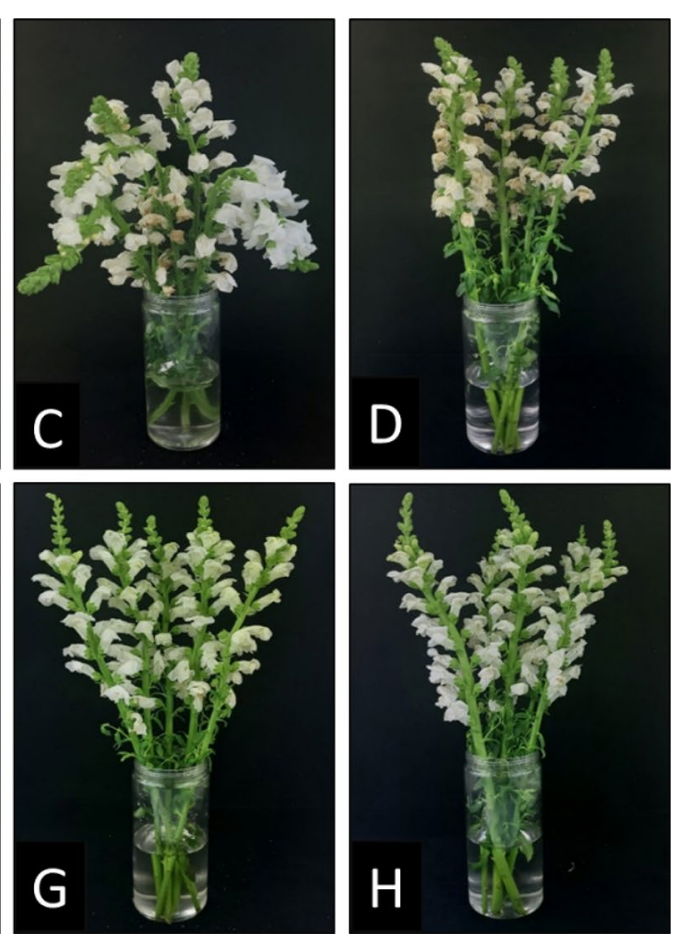

Fig. 1 Comparison of the effects of SNP, STS, ethephon, and control alone or in combination with supplements on the improvement of postharvest quality of snapdragon cut flowers. A Control, B STS, C SNP, D Ethephon, E Control + (BA, GA $\left.3, \mathrm{CaCl}_{2}\right), \mathbf{F} \mathrm{STS}+\left(\mathrm{BA}, \mathrm{GA}_{3}, \mathrm{CaCl}_{2}\right), \mathbf{G} \mathrm{SNP}+(\mathrm{BA}, \mathrm{GA} 3$, $\mathrm{CaCl} 2), \mathbf{H}$ Ethephon $+(\mathrm{BA}, \mathrm{GA} 3, \mathrm{CaCl} 2)$. The photos were taken at $9 \mathrm{DAT}$ 
Table 2 Effect of ethephon, STS, and SNP alone or in combination with supplements on stem bending at 3, 6, and 9 days after treatment

\begin{tabular}{llll}
\hline Treatment & \multicolumn{3}{l}{ Bent stem (\% of total) } \\
\cline { 2 - 4 } & 3D & 6D & 9D \\
\hline Control & 0 & $50 \mathrm{~b}$ & $65 \mathrm{C}$ \\
STS & 0 & $55 \mathrm{a}$ & $100 \mathrm{a}$ \\
SNP & 0 & $20 \mathrm{c}$ & $50 \mathrm{c}$ \\
Ethephon & 0 & $0 \mathrm{~d}$ & $0 \mathrm{e}$ \\
Control $+\left(\mathrm{BA}_{1} \mathrm{GA}_{3}, \mathrm{CaCl}_{2}\right)$ & 0 & $0 \mathrm{~d}$ & $30 \mathrm{~d}$ \\
STS+ $\left(\mathrm{BA}, \mathrm{GA}_{3}, \mathrm{CaCl}_{2}\right)$ & 0 & $40 \mathrm{~b}$ & $88 \mathrm{~b}$ \\
SNP + $\left(\mathrm{BA}, \mathrm{GA}_{3}, \mathrm{CaCl}_{2}\right)$ & 0 & $5 \mathrm{~d}$ & $20 \mathrm{~d}$ \\
Ethephon $+\left(\mathrm{BA}_{1} \mathrm{GA}_{3}, \mathrm{CaCl}_{2}\right)$ & 0 & $0 \mathrm{~d}$ & $0 \mathrm{e}$ \\
\hline
\end{tabular}

Data represent the mean of three replicates, and error bars indicate the standard error. Means with the same letters are not significantly different according to the least significant difference test (LSDT, $\mathrm{p}<0.05)$

the stem bending of the cut snapdragon by assessing several factors associated with stem bending. Moreover, the effects of supplements on stem bending and petal senescence were also investigated.

\section{Results}

\section{Stem curvature and bending}

The degree of stem curvature observed in the control treatment was significantly higher than those of the ethephon, SNP, and STS treatments at 3 days after treatment (DAT); the stem curvatures of the treatments were in the order STS $>$ SNP $>$ ethephon. At 6 DAT the curvature degrees had increased in all treatments except ethephon and the curvature induced by STS had overtaken that of the control (STS > control $>$ SNP). Significant increases in the degrees were observed at 9 DAT, particularly for STS and SNP,

Table 3 Effect of ethephon, STS, and SNP alone or in combination with supplements on relative shoot elongation of shoots at 6 days after treatment

\begin{tabular}{llll}
\hline Treatment & \multicolumn{3}{l}{ Relative shoot growth (\% of initial) } \\
\cline { 2 - 4 } & Part I & Part II & Part III \\
\hline Control & $18 \pm 2.3 \mathrm{C}$ & $24 \pm 2 \mathrm{~b}$ & $2 \pm 0.6 \mathrm{~b}$ \\
STS & $14 \pm 1.2 \mathrm{C}$ & $26 \pm 1.5 \mathrm{ab}$ & $4 \pm 0.6 \mathrm{a}$ \\
SNP & $14 \pm 0.6 \mathrm{C}$ & $18 \pm 1.7 \mathrm{c}$ & $2 \pm 0.5 \mathrm{~b}$ \\
Ethephon & $16 \pm 0.6 \mathrm{C}$ & $12 \pm 0.6 \mathrm{~d}$ & $0 \mathrm{c}$ \\
Control $+\left(\mathrm{BA}_{1} \mathrm{GA}_{3}, \mathrm{CaCl}_{2}\right)$ & $34 \pm 2.3 \mathrm{~b}$ & $24 \pm 1.5 \mathrm{~b}$ & $4 \pm 0.3 \mathrm{a}$ \\
STS + $\left(\mathrm{BA}, \mathrm{GA}_{3}, \mathrm{CaCl}_{2}\right)$ & $29 \pm 1.5 \mathrm{~b}$ & $27 \pm 1.5 \mathrm{a}$ & $4 \pm 0.3 \mathrm{a}$ \\
SNP + $\left(\mathrm{BA}, \mathrm{GA}_{3}, \mathrm{CaCl}_{2}\right)$ & $32 \pm 1.2 \mathrm{~b}$ & $24 \pm 1.2 \mathrm{~b}$ & $2 \pm 0.3 \mathrm{~b}$ \\
Ethephon $+\left(\mathrm{BA}_{1} \mathrm{GA}_{3}, \mathrm{CaCl}_{2}\right)$ & $42 \pm 1.5 \mathrm{a}$ & $12 \pm 1 \mathrm{~d}$ & $2 \pm 0.5 \mathrm{~b}$
\end{tabular}

Data represent the mean of three replicates, and error bars indicate the standard error. Means with the same letters are not significantly different according to the least significant difference test (LSDT, $p<0.05)$
Table 4 Effect of ethephon, STS, and SNP alone or in combination with supplements on maintenance of lignin content from the bending zone of the stems at 3, 6 , and 9 days after treatment

\begin{tabular}{lccc}
\hline Treatment & \multicolumn{3}{c}{ Lignin content (A280 $\mathbf{~ m ~}^{-1}$ protein) } \\
\cline { 2 - 4 } & 3D & 6D & 9D \\
\hline Control & $1.2 \pm 0.1 \mathrm{~cd}$ & $0.4 \pm 0.09 \mathrm{C}$ & $0.16 \pm 0.05 \mathrm{~b}$ \\
STS & $1 \pm 0.17 \mathrm{~d}$ & $0.33 \pm 0.01 \mathrm{C}$ & $0.14 \pm 0.01 \mathrm{~b}$ \\
$\mathrm{SNP}$ & $1.5 \pm 0.29 \mathrm{bc}$ & $0.45 \pm 0.1 \mathrm{C}$ & $0.18 \pm 0.01 \mathrm{~b}$ \\
Ethephon & $2.5 \pm 0.29 \mathrm{a}$ & $1.25 \pm 0.14 \mathrm{ab}$ & $0.55 \pm 0.12 \mathrm{a}$ \\
Control $+\left(\mathrm{BA}_{1} \mathrm{GA}_{3}, \mathrm{CaCl}_{2}\right)$ & $1.9 \pm 0.12 \mathrm{~b}$ & $1.34 \pm 0.16 \mathrm{a}$ & $0.45 \pm 0.05 \mathrm{a}$ \\
$\mathrm{STS}+\left(\mathrm{BA}, \mathrm{GA}_{3}, \mathrm{CaCl}_{2}\right)$ & $1.5 \pm 0.17 \mathrm{bc}$ & $0.42 \pm 0.08 \mathrm{C}$ & $0.27 \pm 0.02 \mathrm{~b}$ \\
$\mathrm{SNP}+\left(\mathrm{BA}, \mathrm{GA}_{3}, \mathrm{CaCl}_{2}\right)$ & $1.8 \pm 0.15 \mathrm{bc}$ & $0.99 \pm 0.08 \mathrm{~b}$ & $0.5 \pm 0.06 \mathrm{a}$ \\
Ethephon $+\left(\mathrm{BA}_{1} \mathrm{GA}_{3}, \mathrm{CaCl}_{2}\right)$ & $2.1 \pm 0.1 \mathrm{ab}$ & $1.09 \pm 0.04 \mathrm{ab}$ & $0.62 \pm 0.08 \mathrm{a}$ \\
\hline
\end{tabular}

Data represent the mean of three replicates, and error bars indicate the standard error. Means with the same letters are not significantly different according to the least significant difference test (LSDT, $p<0.05$ )

however the curvatures of the control and SNP were not significantly different. Surprisingly, the increment was not observed in ethephon. The addition of supplements (BA, $\mathrm{GA}_{3}$, and $\mathrm{CaCl}_{2}$ ) to the control, STS, and SNP significantly reduced the degrees of curvature at 3 , 6 , and 9 DAT. However, the supplements did not significantly impact the effect of ethephon on the curvature (Table 1).

No stem bending (stem with an angle of more than $45^{\circ}$ ) was observed at 3 DAT. At 6 DAT, about $50 \%$ of the flowers from the control and STS and 20\% of SNPtreated flowers were bent. At 9 DAT, all flowers from STS were bent, while $65 \%$ and $50 \%$ of the flowers from the control and SNP treatments showed bending, respectively. Surprisingly, no stem bending was observed in the flowers treated with ethephon even at 9 days (Fig. $1 \mathrm{~A}-\mathrm{H}$ ). In addition, adding the supplements to the treatments significantly delayed the stem bending of flowers, except for ethephon (Table 2).

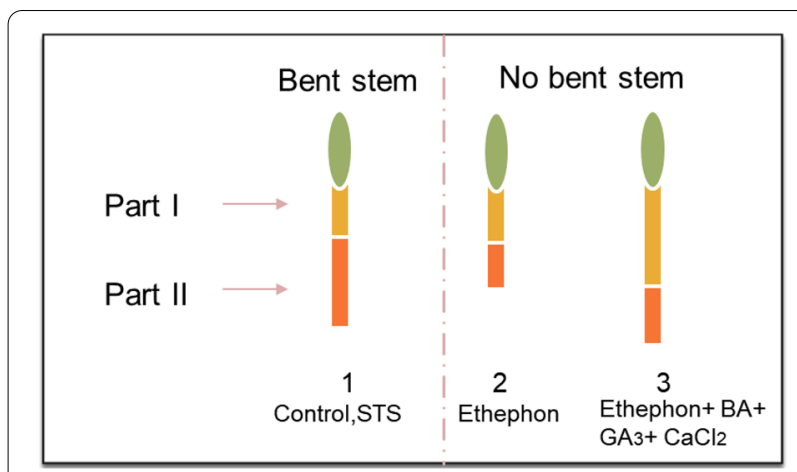

Fig. 2 Comparison of shoot elongation of part I and part II between bent stem and no bent stem 
Table 5 Effect of ethephon, STS, and control on ethylene production from bending zones of the stems at 6 days after treatment

\begin{tabular}{lc}
\hline Treatment & $\begin{array}{l}\text { Ethylene } \\
\text { production } \\
\text { (nl/g/h) }\end{array}$ \\
\hline Control & $4.4 \pm 0.2 \mathrm{~b}$ \\
STS & $2.6 \pm 0.9 \mathrm{c}$ \\
Ethephon & $11.6 \pm 0.2 \mathrm{a}$ \\
\hline
\end{tabular}

Data represent the mean of three replicates, and error bars indicate the standard error. Means with the same letters are not significantly different according to the least significant difference test (LSDT, $\mathrm{p}<0.05$ )

Relative shoot elongation (RSE)

The RSE observed in the different zones differed significantly. Among the three zones, the RSE of part II was the highest, followed by part I and part III. The RSE was not significantly different in part I for all treatments, while the RSE of part II was observed in the order STS and control $>$ SNP $>$ ethephon (Table 3). In part III, ethephon did not completely stimulate stem elongation, while those stimulated by control and SNP were the same and significantly lower than that stimulated by STS. The addition of supplements to the treatments significantly or slightly stimulated RSE depending on the treatments. Based on these results, the RSE results observed in part II were more likely to be associated with a higher bending rate than those of RSE in part I. This was further proved by comparing the RSE results of parts I and II between the bending and unbending stems (Fig. 2).

\section{Lignin content and ethylene production}

Among all treatments (control, STS, SNP, and ethephon), the lignin content obtained from the ethephontreated stems was the highest throughout the vase life period. However, the lignin contents of the stems obtained from control, SNP, and STS treatments were not significantly different, despite the presence of different lignin contents in the treatments $(\mathrm{SNP}>$ control $>$ STS) (Table 4). Continuous reduction of the lignin content was observed in all treatments along with increasing vase life periods, but the addition of the supplements to the treatments promoted lignin content in all treatments, except for ethephon, throughout the vase life period. Ethylene production in the stem sections of the control, ethephon, and ST, which were excised from the putative bending zone (about $100-150 \mathrm{~mm}$ distance from the apex of the shoot), was assessed at 6 DAT. The ethylene production in the stems was observed to be the highest in ethephon followed by the control and STS (Table 5).
Expression of lignin and ethylene biosynthesis genes The expression levels of phenylalanine ammonia-lyase $(P A L)$ and 4-coumarate, CoA ligase $(4 C L)$ genes involved in lignin biosynthesis, were highest in all treatments at 3 DAT, followed by 6 DAT and 9 DAT, indicating a continuous reduction in gene expression with increasing vase life period (Fig. 3). However, their expression levels were higher in the ethephon than the control and STS throughout the vase life; the expression levels in the control were higher than those in the STS (except at 9 DAT). These results confirm that the lignin contents in the treatments were generally consistent with the expression levels of the lignin biosynthetic genes. Expression levels of ethylene biosynthesis genes, such as 1-aminocyclopropane-1-carboxylic acid (ACC) synthetase 1 (ACS1), ACC oxidase (ACO1), and ACC oxidase 2 (ACO2), in the stems were also assessed to reveal the association between their expression and ethylene production. The expression level of $A C S 1$ was significantly higher in the ethephon than in the control and STS, despite no significant differences of expression between the control and STS. In contrast to $A C S 1, \mathrm{ACO} 1$ expression levels were not significantly different among the treatments, but $A C O 2$ expression in the ethephon was observed to be the highest, followed by the control and STS (Fig. 4). Ethylene production was more likely associated with the expression levels of $A C O 2$, rather than those of $A C S 1$ and $A C O 1$.

\section{The petal senescence}

When assessing how petal senescence was affected by the treatments, no senescence was observed in the control, SNP, or STS at 3 DAT; however, $20 \%$ of the flowers treated with ethephon exhibited senescence. At 6 DAT, senescence occurred in all treatments. The order of the senescence rate was as follows: ethephon $>$ control $>$ SNP $>$ STS .

Table 6 Effect of ethephon, STS, and SNP alone or in combination with supplements on petal senescence at 3, 6, and 9 days after treatment

\begin{tabular}{llll}
\hline Treatment & \multicolumn{3}{l}{ Petal senescence (\% of total) } \\
\cline { 2 - 4 } & 3D & 6D & 9D \\
\hline Control & o b & $40 \pm 4 \mathrm{ab}$ & $60 \pm 5.8 \mathrm{~b}$ \\
STS & $0 \mathrm{~b}$ & $25 \pm 2.9 \mathrm{~b}$ & $40 \pm 5.8 \mathrm{c}$ \\
SNP & $0 \mathrm{~b}$ & $30 \pm 2.9 \mathrm{~b}$ & $60 \pm 2.9 \mathrm{~b}$ \\
Ethephon & $20 \pm 4 \mathrm{a}$ & $50 \pm 7.6 \mathrm{a}$ & $90 \pm 4 \mathrm{a}$ \\
Control $+\left(\mathrm{BA}, \mathrm{GA}_{3}, \mathrm{CaCl}_{2}\right)$ & $0 \mathrm{~b}$ & $25 \pm 5 \mathrm{~b}$ & $50 \pm 8.7 \mathrm{bc}$ \\
STS + $\left(\mathrm{BA}, \mathrm{GA}_{3}, \mathrm{CaCl}_{2}\right)$ & $0 \mathrm{~b}$ & $30 \pm 2.9 \mathrm{ab}$ & $40 \pm 2.9 \mathrm{c}$ \\
SNP + $\left(\mathrm{BA}, \mathrm{GA}_{3}, \mathrm{CaCl}_{2}\right)$ & $0 \mathrm{~b}$ & $35 \pm 5 \mathrm{ab}$ & $50 \pm 5 \mathrm{bc}$ \\
Ethephon $+\left(\mathrm{BA}_{2} \mathrm{GA}_{3}, \mathrm{CaCl}_{2}\right)$ & $0 \mathrm{~b}$ & $35 \pm 3 \mathrm{ab}$ & $50 \pm 2.9 \mathrm{bc}$
\end{tabular}

Data represent the mean of three replicates, and error bars indicate the standard error. Means with the same letters are not significantly different according to the least significant difference test (LSDT, $\mathrm{p}<0.05$ ) 

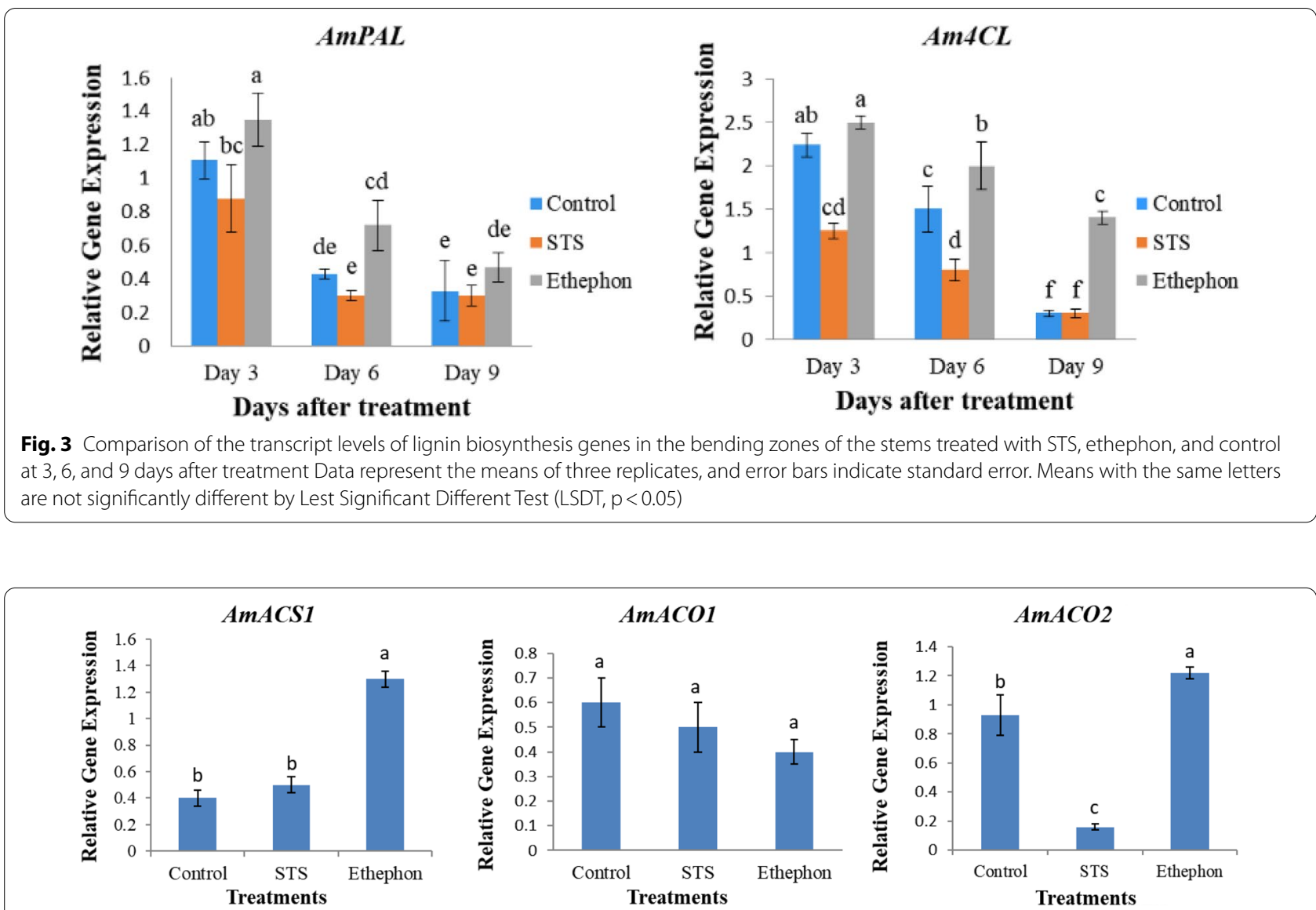

Fig. 4 Comparison of the transcript levels of ethylene biosynthesis genes in the bending zones of the stems treated with STS, ethephon, and control at 6 days after treatment Data represent the means of three replicates, and error bars indicate standard error. Means with the same letters are not significantly different by Lest Significant Different Test (LSDT, $p<0.05$ )

When the vase life period was extended to 9 days, $90 \%$ of the flowers treated with ethephon showed petal wilting and browning at the corner in half of the flower spikes, compared to $60 \%$ in the control and SNP treatments (Table 4). Overall, compared to the control, STS significantly reduced petal senescence and ethephon rapidly accelerated senescence. However, no significant effect on senescence was observed between the SNP and control at 6 and 9 DAT. The addition of the supplements (BA, $\mathrm{GA}_{3}$, and $\mathrm{CaCl}_{2}$ ) to the control, STS, and SNP treatments did not significantly affect petal senescence; however, the addition of the supplements significantly reduced senescence (from 90 to 50\%) in the flowers treated with ethephon at 9 DAT (Table 6).

\section{Discussion}

In this study, we investigated the effects of ethephon, STS, and SNP individually or in combination with supplements on the stem bending of snapdragon by assessing several factors, such as stem curvature, stem bending rate, RSE, lignin content, and ethylene production, and their related gene expression. In addition, their effects on petal senescence were assessed.

The curvature degree results were significantly correlated with the stem bending rates throughout the vase life period for all treatments. In addition, at 9 DAT, the lack of significant difference in the bending rate between the control and SNP was also associated with no significant difference of their curvatures. We found that SNP did not effectively inhibit curvature when the vase life period was extended to 9 days. However, SNP has been reported to delay stem bending in gerberas and Calendula officinalis $[3,14,15]$. This different outcome could be due to the difference in the nature of the stem structures between snapdragon and gerberas and Calendula officinalis. The prevention of stem bending by ethephon or enhancement of stem bending by STS observed in this study was consistent with the work of Naing et al. [2], who recently reported the preventive role of ethephon in stem bending and the stimulatory role of STS in stem bending in other snapdragon cultivars. However, our results were 
not consistent with the results of previous studies that reported the inhibition of stem curvature by STS or $1-\mathrm{MCP}[6,7]$. In addition, our results differed from those of Celikel et al. [5], who suggested that ethylene inhibitors did not significantly affect the gravitropic curvature and bending of snapdragon.

In addition to the curvature degree, RSE also affected stem bending; the RSE results of all treatments observed in part II (STS > control $>$ SNP > ethephon) were correlated with bending rates. In addition, the RSE observed in part II of bending stems was obviously longer than that of unbending stems, unlike in part I (Fig. 3). The RSE in part III was relatively lower compared to that in the other parts (II and I); thus, it would not affect bending. Inhibition of stem elongation in cut flowers by ethephon [2, $9,11]$ and delaying stem bending by its application in vase life solution have been reported in previous studies $[2,11,16]$. In this study, higher reduction of bending rate by SNP over control at 6 DAT was associated with a significant reduction of RSE in part II. Previous studies have reported the role of SNPs in delaying stem bending in gerbera and Calendula officinalis L. [3, 14, 15]; however, they did not investigate the role of SNPs in the inhibition of RSE. Our results suggest that the delaying stem of bending using SNP observed in previous studies could partly be also explained by its inhibitory effect on RSE.

In this study, the important role of lignin content in stem bending was observed, whereas the presence of slightly higher content in the treatments caused delaying of the bending rates at 6 and 9 DAT. In addition, the increase in bending rates along with a longer vase life period was linked to continuous decreases in lignin content. Similarly, previous studies have reported that the stem bending of cut flowers is associated with poor lignification mechanism [2-4, 17]. Naing et al. [3] claimed that SNP could maintain lignin content by triggering lignin biosynthetic genes. In this study, SNP did not significantly promote lignin content compared to the control, while ethephon significantly promoted it. The role of ethephon in lignin accumulation via triggering lignin biosynthetic genes ( $P A L$ and $4 C L$ ) and improvement of resistance to stem breakage has been reported in many plant species [13, 18-23]. Therefore, the higher lignin content in the ethephon-treated stems than in other treatments could be due to the accumulation of higher ethylene in the former than in the latter. As expected, there were significant or slight associations between ethylene production and lignin content in the treatments. The higher ethylene production in the control than the STS treatment supported the presence of higher lignin content in the stems of the former. The expression levels of $P A L$ and $4 C L$ in ethephon, STS, and control were correlated with lignin content. $A C O$ and $A C S$ genes are involved in ethylene biosynthesis in plants, as well as other cellular processes such as cell wall and membrane metabolisms, by switching on signal transduction on ethylene $[24,25]$. In this study, expression of ACO2 was associated with ethylene production at 6 DAT. Therefore, expression of $A C O 2, P A L$, and $4 C L$ at 6 DAT also supported the association between ethylene and lignin production. The maintenance of lignin content at lower levels by SNP than ethephon could be due to the inhibitory effect of SNP on ethylene production, which has been reported in carnations [26].

Unfortunately, ethephon rapidly accelerated petal senescence due to its higher ethylene production, which strongly induces petal senescence and abscission. In contrast, STS significantly reduced petal senescence owing to its inhibitory effect on ethylene production. The role of ethylene in petal senescence and abscission has been reported in various flowers [27, 28]. Various supplements (such as $\mathrm{BA}, \mathrm{GA}_{3}, \mathrm{CaCl}_{2}$, and sugar) have been used to delay stem bending and provide better postharvest quality performance in cut tulip flowers $[11,29]$. Moreover, the role of $\mathrm{CaCl}_{2}$ in delaying stem bending in gerbera cut flowers has been previously reported $[30,31]$. It is likely that $\mathrm{CaCl}_{2}$ maintains cell wall rigidity by binding to pectin molecules, thereby increasing cell wall stiffness that might result in delayed bending $[32,33]$. Moreover, calcium has been reported to reduce the rate of plant senescence [34]. In this study, addition of the supplements $\left(\mathrm{BA}, \mathrm{GA}_{3}\right.$, and $\mathrm{CaCl}_{2}$ ) did not significantly reduce petal senescence in the control, STS, and SNP; however, the supplements relieved the negative effect of ethephon on senescence (from 90 to 50\%) at 9 DAT, as also observed in the study done van Doorn et al. [11]. Another advantage of the supplements was that they reduced the bending rates of the control, STS, and SNP treatments. In summary, at 9 DAT, ethephon completely prevented stem bending of snapdragon cut flowers whereas STS significantly stimulated it. SNP did not significantly affect stem bending compared to the control. Generally, stem bending is linked to a higher degree of curvature and RSE as well as lower ethylene production and lignin content. The combined use of ethephon and supplements can prevent stem bending with a lower rate of petal senescence and is therefore recommended to be used by growers and in the floricultural industry. 


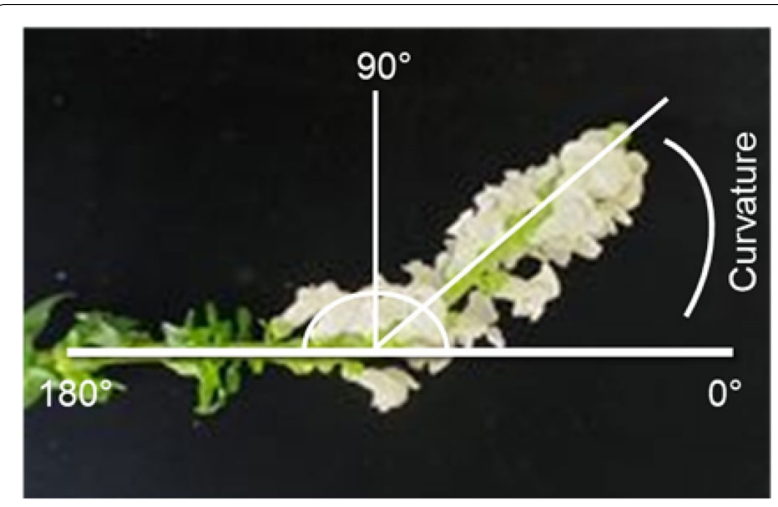

Fig. 5 Illustration of the angle of curvature (degree) of snapdragon spike

\section{Conclusion}

This study demonstrated the effects of ethephon, STS, and SNP on the stem bending of cut snapdragon flowers. Ethephon was found to completely prevent bending within the study period ( 9 days). Moreover, the bending rate of STS was higher than that of the control and SNP did not significantly delay bending compared to the control, particularly at 9 DAT. Stem bending was correlated with degree of stem curvature, RSE, ethylene production, and lignin content and this was proven by expression analysis of genes involved in the ethylene and lignin biosynthetic pathways. The combined use of supplements also delayed stem bending and petal senescence. Ethephon most effectively delayed stem bending of snapdragon and combining with supplements relieved approximately half of the ethephoninduced petal senescence. Therefore, we expect that the information obtained from this study would be valuable for prolonging the appearance of cut flowers that face early stem bending problems.

\section{Materials and methods Plant material}

Cut snapdragon flowers (Antirrhinum majus L. Busasol) were obtained from a farm in Busan. Flowers with 4-6 open flowers per inflorescence and free of mechanical and disease defects were selected. These selected flowers were harvested in the early morning and immediately transported to the laboratory of Kyungpook National University, a journey of 1-2 h. The flowers were horizontally placed in flower box during transportation. After arriving at the laboratory, the flower stems were trimmed to a length of $50 \mathrm{~cm}$ and excess leaves were gently removed.

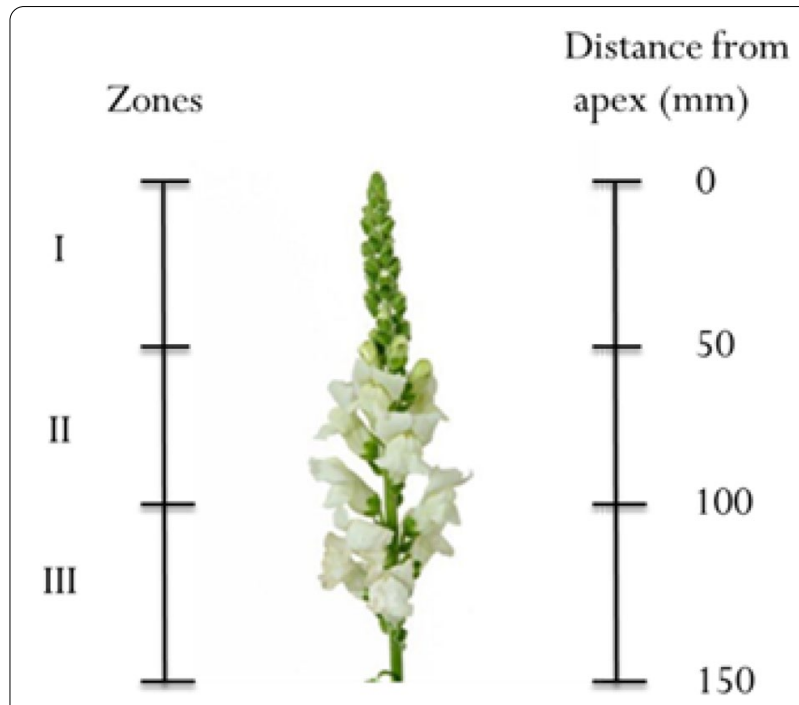

Fig. 6 Illustration of the dividing of the three different parts of shoots for investigation of relative shoot elongation of snapdragon cut flowers

Treating cut flowers with STS, ethephon, and SNP alone or in combination with supplements

Prior to treating the cut flowers, a stock solution of silver thiosulfate (STS) was prepared by adding $0.2 \mathrm{mM}$ silver nitrate (Sigma Aldrich) to $1.2 \mathrm{mM}$ sodium thiosulphate (Sigma Aldrich). The cut flowers were separately placed in bottles $(1 \mathrm{~L})$ containing $0.2 \mathrm{mM}$ of STS, $67 \mathrm{mM}$ of sodium nitroprusside (SNP; Sigma Aldrich), and $0.25 \mathrm{mM}$ of 2-chloroethylphosphonic acid (ethephon; Sigma Aldrich), with or without supplements [0.75 mM of Gibberellic acid $3\left(\mathrm{GA}_{3}\right.$; Duchefa Biochemie) $+0.25 \mathrm{mM}$ of benzyladenine (BA; Duchefa Biochemie $)+10 \mathrm{mM}$ of calcium chloride $\left(\mathrm{CaCl}_{2}\right.$, Duchefa Biochemie)]. Flowers placed in bottles containing only distilled water were used as controls. One treatment contained three bottles with ten flowers per bottle. The treatment concentration ranges were determined based on previous studies $[11,26]$. After treatment for $24 \mathrm{~h}$, the stems were thoroughly washed with tap water and placed into new bottles containing only distilled water $(500 \mathrm{~mL})$. The bottles were then maintained in a controlled chamber at a temperature of $20{ }^{\circ} \mathrm{C}$, relative humidity of $60 \%$, light intensity of $15 \mu \mathrm{mol} \mathrm{m} \mathrm{m}^{2} \mathrm{~s}^{-1}$, and photoperiod of $12 \mathrm{~h}$.

\section{Measurement of angle of curvature (degree)}

Induction of the stem curvature is the first phase of stem bending. In this study, we investigated whether ethephon, STS, and SNP could control the degree of stem curvature of snapdragon cut flowers. Stem curvature was measured using a protractor and described in degrees (Fig. 5). A 
stem curvature of $0^{\circ}$ was defined as a straight stem. The stem gets closer to bending as the curvature gets closer to $180^{\circ}$. The upper part of the stem with an angle of more than $45^{\circ}$ was considered as a bent stem, as a stem with a curvature of more than $45^{\circ}$ is not fit for commercial purposes. The curvature of all stems (30) was measured on days 3, 6, and 9 after treatment (DAT). Each measurement contained ten flower stems and was performed three times.

\section{Bent stem (\% of total)}

The stems that exhibited degrees of curvature greater than $45^{\circ}$ were considered to be bent stems. The bent stems were counted at 3,6 , and 9 DAT and the results were described as percentages.

\section{Relative shoot elongation (SRE) (millimeter)}

To clarify whether stem bending was associated with RSE, elongation was assessed. Briefly, the shoots were divided into three zones: zones I, II, and III starting from the apex of the inflorescence stem at $50 \mathrm{~mm}$ intervals. The zones were marked with a felt pen before pulsing with chemical treatment (Fig. 6). The elongated length was monitored at 6 DAT and described in millimeters $(\mathrm{mm})$. Each treatment contained ten flowers and the measurements were repeated three times.

\section{Analysis of lignin content}

Lignin analysis was performed according to the method described by Syros et al. [35]: stem parts from the bending zone, which were sampled at 3, 6, and 9 DAT, were pulverized in $95 \%$ ethanol using a mortar and pestle. Then, the homogenates were centrifuged at $1000 \mathrm{~g}$ for $10 \mathrm{~min}$. The pellets were washed with $95 \%$ ethanol and $95 \%$ ethanol: $n$-hexane solution $(1: 2 \mathrm{v} / \mathrm{v})$ three times. After drying, $20 \mathrm{mg}$ of the deposits were dissolved in $0.5 \mathrm{~mL}$ of $25 \%$ acetyl bromide in ice acetic acid for $30 \mathrm{~min}$ at $70{ }^{\circ} \mathrm{C}$. After rapid cooling, $0.9 \mathrm{~mL} \mathrm{NaOH}(2 \mathrm{M})$ was added to stop the reaction, which was followed by the addition of $0.1 \mathrm{~mL}$ hydroxylamine- $\mathrm{HCl}(7.5 \mathrm{M})$ and $5 \mathrm{~mL}$ ice acetic acid. Then, $0.1 \mathrm{~mL}$ of reaction mixture was diluted with $3 \mathrm{~mL}$ of ice-cold acetic acid. After centrifugation at $1000 \times \mathrm{g}$ for $5 \mathrm{~min}$, the supernatant was measured at $280 \mathrm{~nm}$. Lignin content was expressed as a $280 \mathrm{mg}^{-1}$ protein. Three independent bending zones were used.

\section{Measurement of ethylene production}

Ethylene production was analyzed from the bending zones of stems treated with STS, ethephon, and control. The bending zones were sampled from 6 DAT. Samples of approximately $2-3 \mathrm{~g}$ were placed in $30 \mathrm{~mL}$ Erlenmeyer flasks, sealed with rubber serum caps, and incubated for $20 \mathrm{~h}$ at room temperature for ethylene accumulation. Ethylene production was measured using gas chromatography $(7820 \mathrm{GC})$ and the ethylene production rates were calculated and expressed as described by $\mathrm{Xu}$ et al. [36]. Three independent bending zones were used for each analysis and analysis was performed three times.

\section{Expressional analysis of genes involved in lignin and ethylene biosynthesis}

Total RNA was extracted from $100 \mathrm{mg}$ stem segments from the bending zones, which were sampled at 3, 6, and 9 DAT using the RNeasy Plant Mini Kit (Qiagen, Hilden, Germany). The cDNA was synthesized from $1 \mu \mathrm{g}$ of total RNA using an oligo dT20 primer and a reverse transcription kit (ReverTra Ace-á, Toyobo, Japan). The mRNA levels of the lignin biosynthetic genes (PAL (DQ866660.1) and 4CL (Y15607.1)) were analyzed at 3, 6, and 9 DAT, but those of ethylene biosynthetic genes (ACS1 (AF083814.2), ACO1 (AY333925.1), and ACO2 (AY333926.1)) were analyzed only at 6 DAT, using the StepOnePlus Real-Time PCR system (Thermo Fisher Scientific, Waltham, MA, United States). Relative gene expression was calculated using the quantitative-comparative method $C_{\mathrm{T}}\left(\Delta \Delta C_{\mathrm{T}}\right)$. The primers and PCR conditions used for this analysis were listed in Additional file 1: Table S1. Three independent bending zones were used for each analysis and analysis was performed three times.

\section{Petal senescence}

Petal senescence was assessed by observing wilting and browning at the corners of the petals. When more than $50 \%$ of the petals from the inflorescence showed senescing symptoms, the flowers were considered to be senescing. Senescence was evaluated in all flowers at 3, 6, and 9 DAT, and the data were expressed as parentages.

\section{Statistical analysis}

Data were analyzed using SPSS v. 11.09 (IBM Corporation, Armonk, NY, USA) and presented as the mean of the three replicates. The least significant difference test was used to assess the differences between mean values. The significance level was set at a P-value $<0.05$.

\section{Abbreviations}

4CL: 4-coumarate: CoA ligase; ACS1: 1-Aminocyclopropane-1-carboxylic acid synthetase 1; ACO1: 1-Aminocyclopropane-1-carboxylic acid oxidase 1; ACO2: 1-Aminocyclopropane-1-carboxylic acid oxidase 2; BA: 6-Benzyladenine; $\mathrm{CaCl}_{2}$ : Calcium chloride; $\mathrm{GA}_{3}$ : Gibberellic acid 3; PAL: Phenylalanine ammonia-lyase; SNP: Sodium nitroprusside; STS: Silver thiosulfate. 


\section{Supplementary Information}

The online version contains supplementary material available at https://doi. org/10.1186/s13007-021-00835-1.

Additional file 1: Table S1. Primer sequences used for the detection of genes related to ethylene biosynthesis and lignin biosynthesis by qRT-PCR.

\section{Acknowledgements}

Not applicable.

\section{Authors' contributions}

AHN designed the study. MTS conducted the experiments and analysed the data. AHN wrote and revised the manuscript. SRK assisted the experiment. CKK supervised the project. All authors read and approved the final manuscript.

\section{Funding}

This work was supported by the National Research Foundation (NRF) grant funded by the Korean government (MSIT) (No. 2021R1A2C2008951).

\section{Availability of data and materials}

All datasets used in this study are available from the corresponding author on reasonable request.

\section{Declarations}

Ethics approval and consent to participate

Not applicable.

\section{Consent for publication}

Not applicable.

\section{Competing interests}

The authors report no conflicts of interests.

\section{Author details}

'Department of Horticulture, Kyungpook National University, Daegu 41566, South Korea. ${ }^{2}$ School of Food Science and Biotechnology, Kyungpook National University, Daegu 41566, South Korea.

Received: 26 October 2021 Accepted: 29 December 2021

Published online: 13 January 2022

\section{References}

1. Asrar A-WA. Effects of some preservative solutions on vase life and keeping quality of snapdragon (Antirrhinum majus L.) cut flowers. J Saudi Soc Agric Sci. 2012;11:29-35.

2. Naing AH, Soe MT, Yeum JH, Kim CK. Ethylene acts as a negative regulator of the stem bending mechanism of different cut snapdragon cultivars. Front Plant Sci. 2021;12:2149.

3. Naing AH, Lee $\mathrm{K}, \mathrm{Kim} \mathrm{KO}, \mathrm{Ai} \mathrm{TN}$, Kim CK. Involvement of sodium nitroprusside (SNP) in the mechanism that delays stem bending of different gerbera cultivars. Front Plant Sci. 2017;8:2045.

4. Cinotti A, Ferrante A, Serra G, Tognoni F. Stem bending study of cut Gerbera jamesonii H. Bolus flowers. Cult Protette. 2005;34:131-6.

5. Çelikel FG, Cevallos JC, Reid MS. Temperature, ethylene and the postharvest performance of cut snapdragons (Antirrhinum majus). Sci Hortic. 2010;125(3):429-33.

6. Philosoph-Hadas S, Meir S, Rosenberger I, Halevy AH. Regulation of the gravitropic response and ethylene biosynthesis in gravistimulated snapdragon spikes by calcium chelators and ethylene inhibitors. Plant Physiol. 1996;110:301-10.

7. Philosoph-Hadas S, Friedman H, Berkovitiz-Simantov R, Rosenberger I, Woltering EJ, Halevy AH, Meir S. Involvement of ethylene biosynthesis and action in regulation of the gravitropic response of cut flowers. In: Kanellis AK, Chang C, Klee H, Bleecker AB, Pech JC, Grierson D, editors.
Biology and biotechnology of the plant hormone ethylene II. Dordrecht: Springer; 1999.

8. Woltering EJ, Balk PA, Nijenhuis-Devries MA, Faivre M, Ruys G, Somhorst D, Philosoph-Hadas S, Friedman H. An auxin-responsive 1-aminocyclopropane-1-carboxylate synthase is responsible for differential ethylene production in gravistimulated Antirrhinum majus L. flower stems. Planta. 2005:220:403-13.

9. Miller WB, Mattson NS, Xie X, Xu D, Currey CJ, Clemens KL, Lopez RG, Olrich M, Runkle ES. Ethephon substrate drenches inhibit stem extension of floriculture crops. HortScience. 2012;47:1312-9.

10. Saniewski M, de MunkWJ. Hormonal control of shoot elongation in tulips. Sci Hortic. 1981;15:363-72.

11. van Doorn WG, Perik PRJ, Perik Abadie P, Harkeme H. A treatment to improve the vase life of cut tulips: effects on tepal senescence, tepal abscission, leaf yellowing and stem elongation. Postharvest Biol Technol. 2011:61:56-6.

12. Wang $X$, Arancibia RA, Main JL, Shankle MW, LaBonte DR. Preharvest foliar applications of ethephon increase skin lignin/suberin content and resistance to skinning in sweetpotato storage roots. HortScience. 2013:48(10):1270-4.

13. Huang WN, Liu HK, Zhang HH, Chen Z, Guo YD, Kang YF. Ethyleneinduced changes in lignification and cell wall-degrading enzymes in the roots of mungbean (Vigna radiata) sprouts. Plant Physiol Biochem. 2013;73:412-9.

14. Hemati E, Daneshvar MH, Heidari M. The roles of sodium nitroprusside, salicylic acid, and methyl jasmonate as hold solutions on vase life of Gerbera jamesonii'Sun Spot.' Adv Hortic Sci. 2019;33(2):187-95.

15. Lone ML, Haq A, Farooq S. Nitric oxide effectively curtails neck bending and mitigates senescence in isolated flowers of Calendula officinalis L. Physiol Mol Biol Plants. 2021;27:835-45.

16. Moe R. The use of ethephon to control plant height in narcissus and tulips. Acta Hortic. 1980;109:197-204.

17. Perik PRJ, Razé D, Harkema H, Zhong Y, van Doorn WG. Bending in cut Gerbera jamesonii flowers relates to adverse water relations and lack of stem sclerenchyma development, not to expansion of the stem central cavity or stem elongation. Postharvest Biol Technol. 2012;74:11-8.

18. Luo ZS, Xu XL, Cai ZZ, Yan M. Effects of ethylene and 1-methylcyclopropene (1-MCP) on lignification of postharvest bamboo shoot. Food Chem. 2007; 105:521-7.

19. Mangieri MA, Mantese Al, Alvarez Schurmann A, Chimenti CA. Effects of ethephon on anatomical changes in sunflower (Helianthus annuus L.) stems associated with lodging. Crop Pasture Sci. 2016:67:988-99.

20. Figueroa NE, Gatica-Meléndez C, Figueroa CR. Ethylene application at the immature stage of Fragaria chiloensis fruit represses the anthocyanin biosynthesis with a concomitant accumulation of lignin. Food Chem. 2021:358:129913.

21. Zhang Y, Wang Y, Ye D, Xing J, Duan L, Li Z, Zhang M. Ethephon-regulated maize internode elongation associated with modulating auxin and gibberellin signal to alter cell wall biosynthesis and modification. Plant Sci. 2020;290:110196.

22. Ye DL, Zhang YS, Al-Kaisi MM, Duan LS, Zhang MC, Li ZH. Ethephon improved stalk strength associated with summer maize adaptations to environments differing in nitrogen availability in the North China Plain. J Agric Sci. 2016;154:960-77.

23. Nascimento VL, Pereira AM, Siqueira JA, Pereira AS, Silva VF, Costa LC, Ribeiro DM, Zsögön A, Nunes-Nesi A, Araújo WL. Exogenous ethylene reduces growth via alterations in central metabolism and cell wall composition in tomato (Solanum lycopersicum). J Plant Physiol. 2021;263:153460

24. Alonso JM, Stepanova AN. The ethylene signalling pathway. Science. 2004;306(5701):1513-5

25. Ahmadizadeh M, Chen JT, Hasanzadeh S, Ahmar S, Heidari P. Insights into the genes involved in the ethylene biosynthesis pathway in Arabidopsis thaliana and Oryza sativa. J Genet Eng Biotechnol. 2020;18:62.

26. Naing AH, Lee K, Arun M, Lim KB, Kim CK. Characterization of the role of sodium nitroprusside (SNP) involved in long vase life of different carnation cultivars. BMC Plant Biol. 2017;17:149.

27. Naing AH, Kim CK. Application of nano-silver particles to control the postharvest biology of cut flowers: a review. Sci Hortic. 2020;270:109463. 
28. Naing AH, Soe MT, Kyu SY, Kim CK. Nano-silver controls transcriptional regulation of ethylene- and senescence-associated genes during senescence in cut carnations. Sci Hortic. 2021;287:110280.

29. Pisulewski TR, Goszczynska DM, Rudnicki RM. The influence of gibberellic acid and ethrel on cut tulips. Acta Hortic. 1989;251:115-8.

30. Gerasopoulos D, Chebli B. Effects of pre- and postharvest calcium applications on the vase life of cut gerberas. J Hortic Sci Biotechnol. 1999;74:78-88.

31. Perik RR, Raze D, Ferrante A, van Doorn WG. Stem bending in cut Gerbera jamesonii flowers: effects of a pulse treatment with sucrose and calcium ions. Postharvest Biol Techn. 2014;98:7-13.

32. Brummell DA. Cell wall disassembly in ripening fruit. Funct Plant Biol. 2006;33:103-19.

33. Cosgrove DJ. Growth of the plant cell wall. Nat Rev Mol Cell Biol. 2005;6:850-86.

34. Ferguson IB. Calcium in plant senescence and fruit ripening. Plant Cell Environ. 1984;7:477-89.

35. Syros T, Yupsanis T, Zafiriadis $H$, Economou AS. Activity and isoforms of peroxidases, lignin and anatomy, during adventitious rooting in cuttings of Ebenus cretica L. J Plant Physiol. 2004;161:69-77.

36. Xu B, Escamilla-Trevino LL, Sathitsuksanoh N, Shen Z, Shen H, Zhang YHP, Dixon RA, Zhao B. Silencing of 4-coumarate: coenzyme A ligase in switchgrass leads to reduced lignin content and improved fermentable sugar yields for biofuel production. New Phytol. 2011;192:611-25.

\section{Publisher's Note}

Springer Nature remains neutral with regard to jurisdictional claims in published maps and institutional affiliations.

- fast, convenient online submission

- thorough peer review by experienced researchers in your field

- rapid publication on acceptance

- support for research data, including large and complex data types

- gold Open Access which fosters wider collaboration and increased citations

- maximum visibility for your research: over $100 \mathrm{M}$ website views per year

At BMC, research is always in progress.

Learn more biomedcentral.com/submissions 